\title{
Clinical significance of HDAC1, -2 and -3 expression levels in esophageal squamous cell carcinoma
}

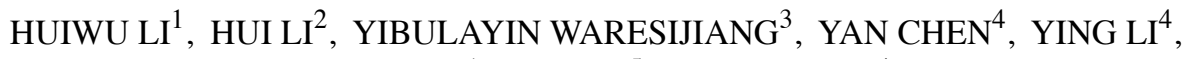 \\ LIANG YU ${ }^{1}$, YIKE $\mathrm{LI}^{5}$ and LING LIU \\ ${ }^{1}$ Medical Research Center, Yubei People's Hospital, Shantou University, Shaoguan, Guangdong 512025; \\ ${ }^{2}$ Department of Central Laboratory; ${ }^{3}$ Department of Thoracic Surgery, Affiliated Cancer Hospital; \\ ${ }^{4}$ Department of Basic Medical College; ${ }^{5}$ First Clinical Medical College, Xinjiang Medical \\ University, Xinshi, Urumqi, Xinjiang Uygur Autonomous Region 830011, P.R. China
}

Received May 8, 2019; Accepted March 3, 2020

DOI: $10.3892 /$ etm.2020.8697

\begin{abstract}
The present study analyzed the expression of the histone deacetylase (HDAC) 1,2 and 3 in primary esophageal squamous cell carcinoma (ESCC) samples and how their levels correlate with clinicopathological parameters. ESCC patients $(n=88)$ in the present study had received no previous treatment before undergoing surgical excision. The mRNA expression of HDAC1, - 2 and -3 were detected by semi-quantified PCR in ESCC samples and distal normal samples. The relationship of HDAC1, -2 and -3 expression with clinicopathological parameters was analyzed by $\chi^{2}$ test. The correlation among these HDACs was analyzed by Pearson's correlation test. Compared with distal normal tissues, ESCC samples had higher expression of HDAC1, but not HDAC2 or HDAC3 $(\mathrm{P}<0.05)$. The expression of HDACs was different between Kazak and Han ethnicities. The expression of HDAC2 was correlated with invasion depth $(\mathrm{P}<0.05)$, but not with sex, age, metastasis, or the degree of tumor differentiation $(\mathrm{P}>0.05)$. There was no association between HDAC1 or HDAC3 and clinicopathological parameters $(\mathrm{P}>0.05)$. For the Kazak and Han ethnicities, HDAC1 expression was present in male patients, patients with well/moderate differentiated ESCC and T3 and T4 ESCC $(\mathrm{P}<0.01)$. HDAC1 in patients aged $<60$ was associated with ethnicity $(\mathrm{P}<0.05)$. HDAC2 expression was different in positive LN metastasis, well/moderate differentiation and T3 and T4 ESCC $(\mathrm{P}<0.01)$. HDAC3 expression in male patients, patients
\end{abstract}

Correspondence to: Associate Professor Ling Liu, Department of Basic Medical College, Xinjiang Medical University, 393 Xinyi Road, Xinshi, Urumqi, Xinjiang Uygur Autonomous Region 830011, P.R. China

E-mail: liulingpine@126.com

Abbreviations: ESCC, esophageal squamous cell carcinoma; HDAC, histone deacetylase

Key words: esophageal squamous cell carcinoma, histone deacetylase 1 , histone deacetylase 2 , histone deacetylase 3 with negative LN metastasis and well/moderate differentiation ESCC was associated with ethnicity $(\mathrm{P}<0.05)$. Additionally, the expression levels of HDAC1, -2 and -3 did not correlate with each other. Thus, HDAC1 expression may be used as a risk factor for ESCC and HDAC2 levels may be used to predict invasion depth. The expression of HDAC1, -2 and -3 has ethnic differences.

\section{Introduction}

Esophageal cancer is the sixth leading cause of cancer-related mortality. It caused the mortality of 440,000 people in 2013 (1). It is the third deadliest cancer in Chinese males and the fifth deadliest malignance in Chinese females (2). In China and other Asian countries, 95\% of the esophageal cancer is esophageal squamous cell carcinoma (ESCC) and the 5-year overall survival rate is $\sim 10-20 \%$ (3). Therefore, it is important to identify the tumor-specific markers in ESCC (4).

Histone deacetylases (HDACs) are expressed in plants, animals, fungi, archaebacteria and eubacteria (5). HDACs are classified into Class I, II and IV or Class III (coenzyme-nicotinamide adenine dinucleotide). HDAC1, $-2,-3$ and -8 belong to Class I (6). HDACs together with histone acetylases can regulate gene transcription and carcinogenesis by modulating chromatin structure (7). Class I HDACs have been shown to be widely expressed in all kinds of solid cancers $(8,9)$. HDAC1 expression in ESCC is higher compared with normal esophageal mucosa. When cancer cells invade the deep layer of the esophageal wall, the expression of HDAC 1 is significantly decreased compared with normal control samples (10). Nevertheless, the expression and role of HDAC2 and 3 in ESCC remain to be elucidated.

The relationship between histone deacetylation and cellular events, including cell proliferation, differentiation and cell cycle regulation has been demonstrated (11-13). For example, HDACs may inhibit target gene expression by binding to the transcriptional cofactor PC3/Tis21, thereby inhibiting cell proliferation (14). HDAC2 overexpression enhances the aggressiveness of gastric carcinoma cells and HDAC2 inhibition attenuates the carcinogenic potential of gastric carcinoma cells in xenotransplanted nude mice (13). 
In addition, several studies have shown that HDAC3 is over-expressed in various solid tumors and is closely associated with poor prognosis (14-16).

The present study investigated the expression levels of HDAC1, -2 and -3 and their clinical significance in ESCC. The association of HDAC1, -2 and -3 with clinicopathological characteristics of ESCC was also analyzed.

\section{Materials and methods}

Patient information and tissue specimens. Primary ESCC tissues and paired distal normal tissues ( $>5 \mathrm{~cm}$ away from the margin of tumor tissue) were collected from 88 patients (Kazak, n=40; Han, n=44). Esophagus excision was performed between December 2009 and September 2015 at the Xinjiang Medical University Affiliated Cancer Hospital. No patient received preoperative chemotherapy or radiotherapy. ESCC diagnosis was confirmed by pathology. Patient characteristics including sex, age, lymph node (LN) metastasis, differentiation and depth of invasion were recorded (Table I). The present study research was approved by the Ethics Committee of Xinjiang Medical University and all patients provided written informed consent.

Reverse transcription semi-quantified PCR. Total RNA was extracted with TRIzol (Invitrogen, Thermo Fisher Scientific, Inc.) from ESCC tissues and paired distal normal tissues. Reverse transcription of RNA was performed with avian myeloblastosis virus reverse transcriptase (Promega Corporation). Reverse transcription was performed under the following heat conditions: $55^{\circ} \mathrm{C}$ for $90 \mathrm{~min}$ and $4{ }^{\circ} \mathrm{C}$ for $10 \mathrm{~min}$. The cDNA products were identified on a $2 \%$ agarose gel with ethidium bromide. The PCR reaction system included $2 \mu 1$ reverse-transcribed cDNA, $10 \mu 1$ 2XPCR master mix,

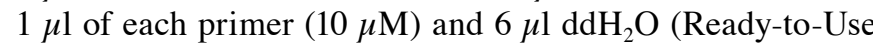
PCR kit, Beijing Transgen Biotech Co., Ltd.). Amplification was performed on an iCycler ${ }^{\mathrm{TM}}$ Thermal Cycler (Bio-Rad Laboratories, Inc.). GAPDH was an internal control.

The PCR primers were: HDAC1 forward, 5'-AGTGCG GTGGTCTTACAGTG-3', HDAC1 reverse, 5'-TCTCCCTCC TCTTCAGAATCG-3', HDAC2 forward, 5'-GCTGGTCTT GAACTCCTT-3', HDAC2 reverse, 5'-TACAACCCATCT GGCATC-3', HDAC3 forward, 5'-GGGACATTATTGGCA GTG-3', HDAC3 reverse, 5'-GGATTCAGGTGTTAGGGA G-3', GAPDH forward, 5'-GCGGGCTCTCCAGAACAT CAT-3' and GAPDH reverse, 5'-CCAGCCCCAGCGTCA AAGGTG-3'. The thermocyling conditions were as follows: Initial denaturation at $95^{\circ} \mathrm{C}$ for $5 \mathrm{~min} ; 35$ cycles of $95^{\circ} \mathrm{C}$ for $30 \mathrm{sec}, 58^{\circ} \mathrm{C}$ for $20 \mathrm{sec}$ for $H D A C 1.54^{\circ} \mathrm{C}$ for $20 \mathrm{sec}$ for $H D A C 2$, $58^{\circ} \mathrm{C}$ for $30 \mathrm{sec}$ for $H D A C 3$ and $60^{\circ} \mathrm{C}$ for $30 \mathrm{sec}$ for $G A P D H$, $72^{\circ} \mathrm{C}$ for $30 \mathrm{~s}$; and a final extension at $72^{\circ} \mathrm{C}$ for $7 \mathrm{~min}$. The PCR products were identified on a $1.5 \%$ agarose gel with ethidium bromide and analyzed with the Gel Doc XR System (Bio-Rad Laboratories, Inc.). The DNA ladder maker was purchased from Sangon Biotech Co., Ltd. The intensities of PCR product bands were quantified using Quantity One software version 4.5.2 (Bio-Rad Laboratories, Inc.). The quantity of each PCR product band was standardized to that of $G A P D H$. The presence or absence of bands was considered positive or negative. Grey scale ratio $>2$ was defined as high expression.
Table I. Clinicopathological characteristics of esophageal squamous cell carcinoma patients.

\begin{tabular}{lr}
\hline Basic data & Number \\
\hline Sex & 62 \\
Male & 26 \\
Female & 48 \\
Ethnicity & 40 \\
Han & \\
Kazakh & \\
Age & 46 \\
$<60$ yrs & 42 \\
$\geq 60$ yrs & 46 \\
LN Metastasis & 42 \\
Positive & \\
Negative & 69 \\
Differentiation & 19 \\
Well and Moderate & \\
Poor & 13 \\
Depth of invasion & 75 \\
T1 and T2 & \\
T3 and T4 &
\end{tabular}

ESCC, esophageal squamous cell carcinoma; LN, lymph node metastases; T1, tumors only invade the lamina propria and submucosa; $\mathrm{T} 2$, tumors invade the muscular layer; T3, tumors invade the esophageal fibrous membrane; T4, tumors invade adjacent organs.

Statistical analysis. SPSS 17.0 software (SPSS Inc.) was used for data analysis. Experiments were performed in triplicate. Measurement data were presented as the mean \pm SD. Count data were expressed as the number (\%). Correlations among HDAC1, -2 and -3 expression were analyzed by the Pearson correlation test. Differences in gene expression were analyzed using a paired t-test and variances in clinicopathologic features were analyzed using $\chi^{2}$ test. $\mathrm{P}<0.05$ was considered to indicate a statistically significant difference.

\section{Results}

Patient characteristics. First, the basic information of the patients was investigated (Table I). Of the 88 patients, 26 $(29.5 \%)$ were women and $62(70.5 \%)$ were men. Their mean age was 58.2 years, $37-84$ years old. The most common tumor location was at the middle and lower esophagus (95.5\%). There were 69 ESCC cases with moderate to high differentiation and 19 with poor differentiation. A total of 46 cases had LN metastasis and $42 \mathrm{did}$ not have LN metastasis. There were 13 cases of $T_{1}+T_{2}$ and 75 cases of $T_{3}+T_{4}$

Expression levels of HDAC1, -2 and -3 in human ESCC and distal normal tissues. To compare the expression levels of $H D A C 1,-2$ and -3 in tumor issues and distal normal tissues, reverse transcription semi-quantified PCR analysis was performed. The representative amplification results of $H D A C 1,-2$ and -3 are presented in Fig. 1A. It demonstrated 
Table II. Expression of $H D A C 1,-2$ and -3 mRNA in tumor and normal tissue.

\begin{tabular}{|c|c|c|c|c|c|c|c|}
\hline Expression of mRNA & Specimens & No & Positive (+) & Negative (-) & Positive rate $(\%)$ & $X^{2}$ & P-value \\
\hline \multirow[t]{2}{*}{ HDAC1 } & $\mathrm{T}$ & 88 & 43 & 45 & $48.9(43 / 88)$ & \multirow[t]{2}{*}{5.312} & \multirow[t]{2}{*}{$0.021^{\mathrm{a}}$} \\
\hline & $\mathrm{N}$ & 88 & 28 & 60 & $31.8(28 / 88)$ & & \\
\hline \multirow[t]{2}{*}{$H D A C 2$} & $\mathrm{~T}$ & 88 & 68 & 20 & $77.3(68 / 88)$ & \multirow[t]{2}{*}{1.828} & \multirow[t]{2}{*}{0.176} \\
\hline & $\mathrm{N}$ & 88 & 75 & 13 & $85.2(75 / 88)$ & & \\
\hline \multirow[t]{2}{*}{$H D A C 3$} & $\mathrm{~T}$ & 88 & 82 & 6 & $93.2(82 / 88)$ & \multirow[t]{2}{*}{1.628} & \multirow[t]{2}{*}{0.202} \\
\hline & $\mathrm{N}$ & 88 & 77 & 11 & $87.5(77 / 88)$ & & \\
\hline
\end{tabular}

${ }^{\mathrm{a}} \mathrm{P}<0.05$. T, Tumor tissues; N, Normal tissues; HDAC, histone deacetylase.

Table III. Expression of HDAC1, HDAC2 and HDAC3 mRNA in tumor and normal tissue of Han and Kazak people.

\begin{tabular}{|c|c|c|c|c|c|c|c|c|c|}
\hline \multirow{2}{*}{$\begin{array}{l}\text { Expression of mRNA } \\
\text { HDAC1 }\end{array}$} & \multirow{2}{*}{$\begin{array}{c}\text { Specimens } \\
\mathrm{T}\end{array}$} & \multicolumn{3}{|c|}{ Positive no. (+) } & \multicolumn{3}{|c|}{ Negative no. (-) } & \multirow{2}{*}{$\begin{array}{c}X^{2} \\
10.443\end{array}$} & \multirow{2}{*}{$\frac{\text { P-value }}{0.001^{\mathrm{a}}}$} \\
\hline & & 43 & Han & 31 & 45 & Han & 17 & & \\
\hline & & & Kazak & 12 & & Kazak & 28 & & \\
\hline & $\mathrm{N}$ & 28 & Han & 21 & 60 & Han & 27 & 6.930 & $0.008^{\mathrm{a}}$ \\
\hline & & & Kazak & 7 & & Kazak & 33 & & \\
\hline \multirow[t]{4}{*}{$H D A C 2$} & $\mathrm{~T}$ & 68 & Han & 44 & 20 & Han & 4 & 12.458 & 0.176 \\
\hline & & & Kazak & 24 & & Kazak & 16 & & \\
\hline & $\mathrm{N}$ & 75 & Han & 46 & 13 & Han & 3 & 6.571 & $0.010^{\mathrm{a}}$ \\
\hline & & & Kazak & 29 & & Kazak & 10 & & \\
\hline \multirow[t]{4}{*}{$H D A C 3$} & $\mathrm{~T}$ & 82 & Han & 48 & 6 & Han & 0 & 7.727 & $0.005^{\mathrm{a}}$ \\
\hline & & & Kazak & 34 & & Kazak & 6 & & \\
\hline & $\mathrm{N}$ & 77 & Han & 45 & 11 & Han & 3 & 3.771 & 0.052 \\
\hline & & & Kazak & 32 & & Kazak & 8 & & \\
\hline
\end{tabular}

${ }^{a} \mathrm{P}<0.05$. T, Tumor tissues; N, Normal tissues; HDAC, histone deacetylase.

A

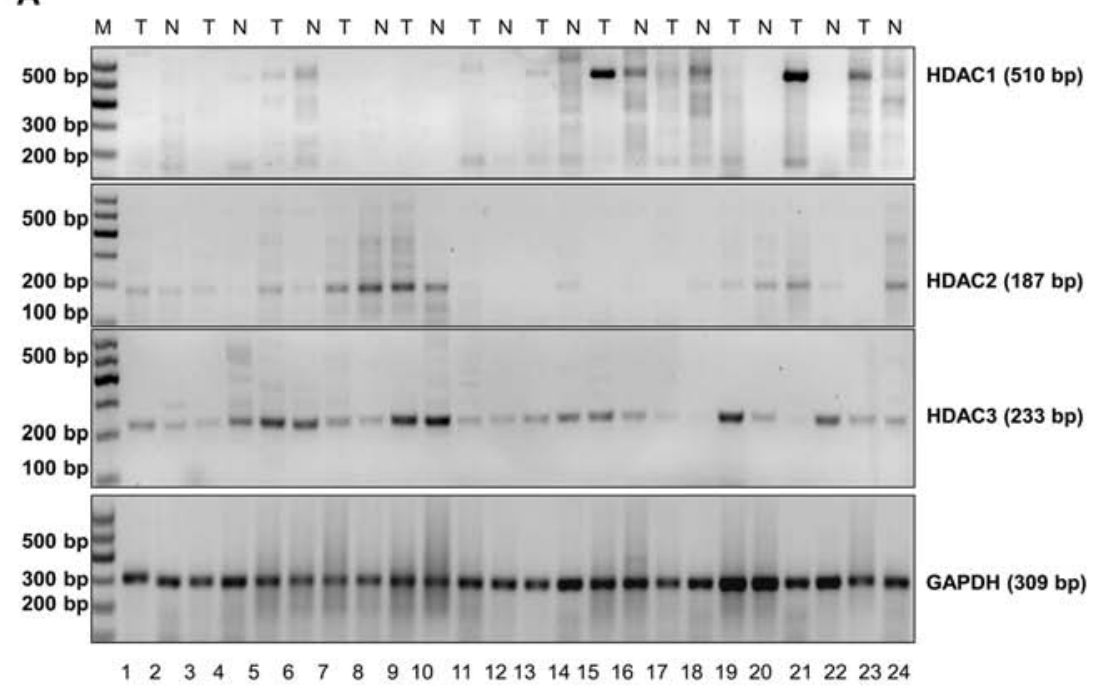

B

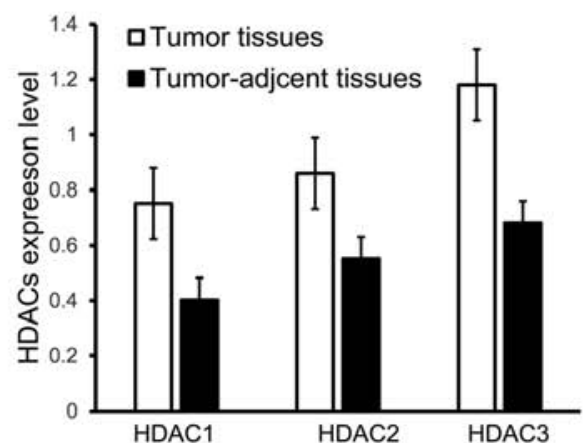

Figure 1. Expression of HDAC1, -2 and -3 mRNA. HDAC1, -2 and -3 mRNA levels in ESCC samples and normal tissues were analyzed by semi-quantified PCR. (A) Representative amplification results of $H D A C 1,-2$ and -3 in patient specimens. (B) Normalized $H D A C 1,-2$ and -3 expression level in human ESCC and normal tissues. T, primary tumor; N, paired normal tissues; M, marker; ESCC, esophageal squamous cell carcinoma; HDAC, histone deacetylase. 
Table IV. Correlation of HDACl expression with clinicopathologic characteristics of esophageal squamous cell carcinoma patients $(n=88)$.

\begin{tabular}{|c|c|c|c|c|c|c|}
\hline \multirow{2}{*}{$\begin{array}{l}\text { Clinicopathological } \\
\text { characteristics }\end{array}$} & \multirow[b]{2}{*}{ No. } & \multicolumn{3}{|c|}{ Expression of $H D A C 1 \mathrm{mRNA}$} & \multirow[b]{2}{*}{$X^{2}$} & \multirow[b]{2}{*}{ P-value } \\
\hline & & Positive (+) & Negative (-) & Positive rate $(\%)$ & & \\
\hline \multicolumn{7}{|l|}{ Sex } \\
\hline Male & 62 & 31 & 31 & $50.0(31 / 62)$ & \multirow[t]{2}{*}{0.108} & \multirow[t]{2}{*}{0.742} \\
\hline Female & 26 & 12 & 14 & $46.2(12 / 26)$ & & \\
\hline \multicolumn{7}{|l|}{ Age } \\
\hline$<60$ yrs & 46 & 20 & 26 & $43.5(20 / 46)$ & \multirow[t]{2}{*}{1.119} & \multirow[t]{2}{*}{0.290} \\
\hline$\geq 60 \mathrm{yrs}$ & 42 & 23 & 19 & $54.8(23 / 42)$ & & \\
\hline \multicolumn{7}{|l|}{ LN Metastasis } \\
\hline Positive & 46 & 22 & 24 & $47.8(22 / 46)$ & \multirow[t]{2}{*}{0.042} & \multirow[t]{2}{*}{0.839} \\
\hline Negative & 42 & 21 & 21 & $50.0(21 / 42)$ & & \\
\hline \multicolumn{7}{|l|}{ Differentiation } \\
\hline Well and Moderate & 69 & 36 & 33 & $52.26(36 / 69)$ & \multirow[t]{2}{*}{1.401} & \multirow[t]{2}{*}{0.236} \\
\hline Poor & 19 & 7 & 12 & $36.8(7 / 19)$ & & \\
\hline \multicolumn{7}{|l|}{ Depth of invasion } \\
\hline $\mathrm{T} 1$ and $\mathrm{T} 2$ & 13 & 6 & 7 & $46.2(6 / 13)$ & \multirow[t]{2}{*}{0.045} & \multirow[t]{2}{*}{0.832} \\
\hline $\mathrm{T} 3$ and T4 & 75 & 37 & 38 & $49.3(37 / 75)$ & & \\
\hline
\end{tabular}

LN, lymph node metastases; T1, tumors only invade the lamina propria and submucosa; T2, tumors invade the muscular layer; T3, tumors invade the esophageal fibrous membrane; T4, tumors invade adjacent organs; HDAC, histone deacetylase.

Table V. Correlation of HDAC2 expression with clinicopathologic characteristics of esophageal squamous cell carcinoma patients $(n=88)$.

\begin{tabular}{|c|c|c|c|c|c|c|}
\hline \multirow{2}{*}{$\begin{array}{l}\text { Clinicopathological } \\
\text { characteristics }\end{array}$} & \multirow[b]{2}{*}{ No. } & \multicolumn{3}{|c|}{ Expression of $H D A C 2$ mRNA } & \multirow[b]{2}{*}{$X^{2}$} & \multirow[b]{2}{*}{ P-value } \\
\hline & & Positive (+) & Negative (-) & Positive rate (\%) & & \\
\hline \multicolumn{7}{|l|}{ Sex } \\
\hline Male & 62 & 47 & 15 & $75.8(47 / 62)$ & 0.257 & 0.612 \\
\hline Female & 26 & 21 & 5 & $80.8(21 / 26)$ & & \\
\hline \multicolumn{7}{|l|}{ Age } \\
\hline$<60$ yrs & 46 & 37 & 9 & $80.4(37 / 46)$ & 0.549 & 0.459 \\
\hline$\geq 60 \mathrm{yrs}$ & 42 & 31 & 11 & $73.8(31 / 42)$ & & \\
\hline \multicolumn{7}{|l|}{ LN Metastasis } \\
\hline Positive & 46 & 39 & 7 & $84.8(39 / 46)$ & 3.095 & 0.079 \\
\hline Negative & 42 & 29 & 13 & $69.0(29 / 42)$ & & \\
\hline \multicolumn{7}{|l|}{ Differentiation } \\
\hline Well and Moderate & 69 & 52 & 17 & $75.4(52 / 69)$ & 0.664 & 0.415 \\
\hline Poor & 19 & 16 & 3 & $84.2(16 / 19)$ & & \\
\hline \multicolumn{7}{|l|}{ Depth of invasion } \\
\hline $\mathrm{T} 1$ and $\mathrm{T} 2$ & 13 & 6 & 7 & 13 & 8.411 & $0.004^{\mathrm{a}}$ \\
\hline $\mathrm{T} 3$ and T4 & 75 & 62 & 13 & 75 & & \\
\hline
\end{tabular}

${ }^{\text {aP }}<0.05$. LN, lymph node metastases; T1, tumors only invade the lamina propria and submucosa; T2, tumors invade the muscular layer; T3, tumors invade the esophageal fibrous membrane; T4, tumors invade adjacent organs; HDAC, histone deacetylase.

that $H D A C 1$ was $510 \mathrm{bp}$ in length, HDAC2 was $187 \mathrm{bp}$, Following quantification, expression of $H D A C 1,-2$ and $H D A C 3$ was 233 bp and $G A P D H$ was 309 bp (Fig. 1A). -3 mRNA was elevated in tumor tissues compared with 
Table VI. Correlation of HDAC3 expression with clinicopathologic characteristics of esophageal squamous cell carcinoma patients $(\mathrm{n}=88)$.

\begin{tabular}{|c|c|c|c|c|c|c|}
\hline \multirow{2}{*}{$\begin{array}{l}\text { Clinicopathological } \\
\text { characteristics }\end{array}$} & \multirow[b]{2}{*}{ No. } & \multicolumn{3}{|c|}{ Expression of $H D A C 3$ mRNA } & \multirow[b]{2}{*}{$X^{2}$} & \multirow[b]{2}{*}{ P-value } \\
\hline & & Positive (+) & Negative (-) & Positive rate (\%) & & \\
\hline \multicolumn{7}{|l|}{ Sex } \\
\hline Male & 62 & 59 & 3 & $95.2(59 / 62)$ & \multirow[t]{2}{*}{1.294} & \multirow[t]{2}{*}{0.255} \\
\hline Female & 26 & 23 & 3 & $88.5(23 / 26)$ & & \\
\hline \multicolumn{7}{|l|}{ Age } \\
\hline$<60 \mathrm{yrs}$ & 46 & 45 & 1 & $97.8(45 / 46)$ & \multirow[t]{2}{*}{3.272} & \multirow[t]{2}{*}{0.070} \\
\hline$\geq 60 \mathrm{yrs}$ & 42 & 37 & 5 & $88.1(37 / 42)$ & & \\
\hline \multicolumn{7}{|l|}{ LN Metastasis } \\
\hline Positive & 46 & 43 & 3 & $93.5(43 / 46)$ & \multirow[t]{2}{*}{0.013} & \multirow[t]{2}{*}{0.908} \\
\hline Negative & 42 & 39 & 3 & $92.9(39 / 42)$ & & \\
\hline \multicolumn{7}{|l|}{ Differentiation } \\
\hline Well and Moderate & 69 & 64 & 5 & $92.8(64 / 69)$ & \multirow[t]{2}{*}{0.092} & \multirow[t]{2}{*}{0.761} \\
\hline Poor & 19 & 18 & 1 & $94.7(18 / 19)$ & & \\
\hline \multicolumn{7}{|l|}{ Depth of invasion } \\
\hline $\mathrm{T} 1$ and $\mathrm{T} 2$ & 13 & 13 & 0 & $100(13 / 13)$ & \multirow[t]{2}{*}{1.116} & \multirow[t]{2}{*}{0.291} \\
\hline $\mathrm{T} 3$ and $\mathrm{T} 4$ & 75 & 69 & 6 & $92.0(69 / 75)$ & & \\
\hline
\end{tabular}

LN, lymph node metastases; T1, tumors only invade the lamina propria and submucosa; T2, tumors invade the muscular layer; T3, tumors invade the esophageal fibrous membrane; T4, tumors invade adjacent organs; HDAC, histone deacetylase.

distal normal tissue, although no significant difference was observed (Fig. 1B). The HDACl mRNAs were positive in $48.9 \%(43 / 88)$ of the tumor tissues, HDAC2 mRNAs were positive in $77.3(68 / 88)$ of the tumor tissues and $H D A C 3$ mRNAs were positive in $93.2 \%(82 / 88)$ of the tumor tissues. Their positive rate in distal normal tissues was $31.8 \%$ $(28 / 88), 85.2 \%(75 / 88)$ and $87.5 \%$ (77/88), respectively. The expression of $H D A C 1$, but not $H D A C 2$ or $H D A C 3$, was higher in ESCC samples than in distal normal samples $(\mathrm{P}<0.05$; Table II). The expression of HDAC1, -2 and -3 in patients of different ethnicities was also analyzed. As shown in Table III, the expression of $H D A C l$ in tumor tissue and normal tissue of Kazak people was lower compared with Han people $(\mathrm{P}<0.05)$. The expression of $H D A C 2$ in normal tissue of Kazak people was decreased compared with that in Han people. The expression of HDAC 3 in tumor tissue of Kazak people was decreased compared with that in Han people $(\mathrm{P}<0.05)$.

Relationship of HDAC1, -2 and -3 expression with clinicopathological characteristics. Next the relationship of HDAC1, -2 and -3 expression with the clinicopathological characteristics of ESCC patients was detected. No significant differences were found in correlation analysis between HDAC1 expression and clinicopathological indexes (Table IV). The expression of HDAC2 was significantly related with invasion depth $(\mathrm{P}<0.05$; Table $\mathrm{V})$. However, there were no significant correlation between HDAC2 and age, sex, depth of invasion and tumor differentiation. Moreover, no significant differences were found between HDAC3 expression and clinicopathological indexes
(Table VI). For the Kazak and Han ethnicities, the expression of HDAC1 in male patients, patients with well and moderate differentiated ESCC and T3 and T4 ESCC were significantly related with ethnicity $(\mathrm{P}<0.01$; Table VII). The expression of HDAC1 in patients less than 60 years old was related with ethnicity $(\mathrm{P}<0.05$; Table VII). The expression of HDAC2 in positive LN metastasis, well and moderate differentiation and T3 and T4 stages were significantly related with ethnicity $(\mathrm{P}<0.01$; Table VIII). The expression of HDAC2 in female patients and negative LN metastasis were related with ethnicity $(\mathrm{P}<0.05$; Table VIII). The expression of HDAC3 in male, negative LN metastasis and well and moderate differentiation was related with ethnicity $(\mathrm{P}<0.05$; Table IX).

Correlation among HDAC1, -2 and -3 expression in human ESCC tissues. The correlation among HDAC1, -2 and -3 was obtained by using Pearson's correlation test. The result showed that there were no significant correlations between HDAC1 and HDAC2 ( $\mathrm{r}=-0.042, \mathrm{P}=0.694), \mathrm{HDAC} 1$ and HDAC3 $(\mathrm{r}=-0.084$, $\mathrm{P}=0.430)$, or HDAC2 and HDAC3 $(\mathrm{r}=-0.176, \mathrm{P}=0.099)$ in ESCC tissues (Fig. 2). These results indicated that there was no correlation among the three HDACs.

\section{Discussion}

ESCC is a common malignant cancer, which can easily invade adjacent areas and metastasize to lymph nodes and distant tissues $(15,16)$. It has a high degree of prevalence and a low survival rate. Thus, it is urgent to develop molecular markers that can facilitate the early detection of ESCC. 
Table VII. Correlation of HDACl expression with clinicopathologic characteristics of esophageal squamous cell carcinoma in Han and Kazak patients $(\mathrm{n}=88)$.

\begin{tabular}{|c|c|c|c|c|c|c|c|c|c|}
\hline \multirow{3}{*}{$\begin{array}{l}\text { Clinicopathological } \\
\text { characteristics }\end{array}$} & \multirow[b]{3}{*}{ Male } & \multicolumn{6}{|c|}{ Expression No. of $H D A C 1$ mRNA } & \multirow{3}{*}{$\begin{array}{c}X^{2} \\
11.328\end{array}$} & \multirow{3}{*}{$\frac{\text { P-value }}{0.001^{\mathrm{a}}}$} \\
\hline & & \multicolumn{3}{|c|}{ Positive No. (+) } & \multicolumn{3}{|c|}{ Negative No. (-) } & & \\
\hline & & 31 & Han & 25 & 31 & Han & 12 & & \\
\hline & & & Kazak & 6 & & Kazak & 19 & & \\
\hline & Female & 12 & Han & 6 & 14 & Han & 5 & 0.540 & 0.462 \\
\hline & & & Kazak & 6 & & Kazak & 9 & & \\
\hline Age & $<60 \mathrm{yrs}$ & 20 & Han & 11 & 26 & Han & 6 & 4.945 & $0.026^{\mathrm{a}}$ \\
\hline & & & Kazak & 9 & & Kazak & 20 & & \\
\hline & $\geq 60 \mathrm{yrs}$ & 23 & Han & 19 & 19 & Han & 12 & 2.036 & 0.154 \\
\hline & & & Kazak & 4 & & Kazak & 7 & & \\
\hline LN Metastasis & Positive & 22 & Han & 13 & 24 & Han & 10 & 1.394 & 0.238 \\
\hline & & & Kazak & 9 & & Kazak & 14 & & \\
\hline & Negative & 21 & Han & 18 & 21 & Han & 7 & 2.059 & 0.151 \\
\hline & & & Kazak & 3 & & Kazak & 14 & & \\
\hline Differentiation & Well and moderate & 36 & Han & 24 & 33 & Han & 11 & 7.654 & $0.006^{\mathrm{a}}$ \\
\hline & & & Kazak & 12 & & Kazak & 22 & & \\
\hline & Poor & 7 & Han & 6 & 12 & Han & 7 & 1.534 & 0.216 \\
\hline & & & Kazak & 1 & & Kazak & 5 & & \\
\hline Depth of invasion & $\mathrm{T} 1$ and $\mathrm{T} 2$ & 6 & Han & 3 & 7 & Han & 2 & 0.627 & 0.429 \\
\hline & & & Kazak & 3 & & Kazak & 5 & & \\
\hline & $\mathrm{T} 3$ and $\mathrm{T} 4$ & 37 & Han & 28 & 38 & Han & 15 & 10.044 & $0.002^{\mathrm{a}}$ \\
\hline & & & Kazak & 9 & & Kazak & 23 & & \\
\hline
\end{tabular}

aP-value was considered statistically significant at $<0.05$. LN, lymph node metastases; T1, tumors only invade the lamina propria and submucosa; T2, tumors invade the muscular layer; T3, tumors invade the esophageal fibrous membrane; T4, tumors invade adjacent organs; HDAC, histone deacetylase.

HDAC1 contains 482 amino acids, identified in 1996 by Taunton et al (17). HDAC1 regulates genes involved in cell differentiation and the cell cycle, and participates in the development of various diseases such as viral infectious diseases, degenerative diseases and cancer (18-20). HDAC1 can mediate site-specific DNA-binding transcriptional repression and a high level of HDAC1 is observed in tumor invasion and metastasis (21). Burdelski et al (22) identified that a high level of HDAC1 was associated with high Gleason grade, advanced pathological tumor stage, positive LN metastasis, elevated preoperative prostate specific antigen level and cell proliferation; therefore, HDAC1 expression detection may have clinical significance for the risk stratification of prostate cancer. Huang et al (23), demonstrated high expression of HDACs in cervical cancer and cervical intraepithelial neoplasia tissues. Mutze et al (24), identified high levels of HDAC1 and HDAC2 in gastric carcinomas and they were not related to the response to platinum/5-fluorouracil. High HDAC1 level is related to lower overall survival (25). There is a significant association between HDAC1 high expression and advanced age (26). High levels of HDACl expression are associated with a poor histological differentiation and prognosis in liver cell carcinoma (27). There is higher expression of HDAC1 in gastrointestinal malignant tumor, particularly in colorectal cancer and HDAC1 expression is closely related to clinical characteristics of gastrointestinal cancer (8). Zhong et al (28), noted that the high expression of HDAC1 may serve as a potential therapeutic target for ESCC. Miyashita et al (29), reported that the expression of HDAC1 may be involved in duodenoesophageal reflux-induced neoplastic transformation of the esophageal mucosa into cancer cells with squamous and adeno differentiation. By contrast, Langer et al (30) stated HDAC1 expression is not changed based on $\mathrm{pT}$, $\mathrm{pN}$ category or esophageal adenocarcinoma differentiation level. Xu et al (31), noted that HERG1 contributes to poor prognosis of ESCC and suggest that targeting HERG1 may have potential diagnostic and therapeutic value for ESCC treatment. In the present study, the positive rate of HDAC1 expression in ESCC was increased compared with normal tissues. However, the expression did not change according to sex, age, metastasis, differentiation degree and invasion depth.

HDAC2 can promote tumorigenesis through several mechanisms, including promoting the degradation of $\beta$-catenin and decreasing epigenetic modification $(15,32)$. In addition, HDAC 2 can inhibit the expression of tumor suppressor p53 and p21 while promoting expression of oncogene Myc $(33,34)$. HDAC2 participates in chronic obstructive pulmonary disease $(35,36)$. It is also over expressed in lung 
Table VIII. Correlation of HDAC2 expression with clinicopathologic characteristics of esophageal squamous cell carcinoma in Han and Kazaks patients $(\mathrm{n}=88)$.

\begin{tabular}{|c|c|c|c|c|c|c|c|c|c|}
\hline \multirow{3}{*}{$\begin{array}{l}\text { Clinicopathological } \\
\text { characteristics }\end{array}$} & \multirow[b]{3}{*}{ Male } & \multicolumn{6}{|c|}{ Expression No. of HDAC1 mRNA } & \multirow{3}{*}{$\frac{X^{2}}{3.184}$} & \multirow{3}{*}{$\frac{P \text {-value }}{0.074}$} \\
\hline & & \multicolumn{3}{|c|}{ Positive (+) No. } & \multicolumn{3}{|c|}{ Negative (-) } & & \\
\hline & & 47 & Han & 31 & 15 & Han & 6 & & \\
\hline & & & Kazak & 16 & & Kazak & 9 & & \\
\hline & Female & 21 & Han & 11 & 5 & Han & 0 & 4.540 & $0.033^{\mathrm{a}}$ \\
\hline & & & Kazak & 10 & & Kazak & 5 & & \\
\hline Age & $<60 \mathrm{yrs}$ & 37 & Han & 17 & 9 & Han & 0 & 6.559 & $0.010^{\mathrm{a}}$ \\
\hline & & & Kazak & 20 & & Kazak & 9 & & \\
\hline & $\geq 60 \mathrm{yrs}$ & 31 & Han & 26 & 11 & Han & 5 & 6.198 & $0.013^{\mathrm{a}}$ \\
\hline & & & Kazak & 5 & & Kazak & 6 & & \\
\hline LN Metastasis & Positive & 39 & Han & 23 & 7 & Han & 0 & 8.256 & $0.004^{\mathrm{a}}$ \\
\hline & & & Kazak & 16 & & Kazak & 7 & & \\
\hline & Negative & 29 & Han & 21 & 13 & Han & 4 & 6.461 & $0.011^{\mathrm{a}}$ \\
\hline & & & Kazak & 8 & & Kazak & 9 & & \\
\hline Differentiation & Well and Moderate & 52 & Han & 32 & 17 & Han & 3 & 9.874 & $0.002^{\mathrm{a}}$ \\
\hline & & & Kazak & 20 & & Kazak & 14 & & \\
\hline & Poor & 16 & Han & 12 & 3 & Han & 1 & 2.030 & 0.154 \\
\hline & & & Kazak & 4 & & Kazak & 2 & & \\
\hline Depth of invasion & $\mathrm{T} 1$ and $\mathrm{T} 2$ & 6 & Han & 4 & 7 & Han & 1 & 3.745 & 0.053 \\
\hline & & & Kazak & 2 & & Kazak & 6 & & \\
\hline & $\mathrm{T} 3$ and $\mathrm{T} 4$ & 62 & Han & 40 & 13 & Han & 3 & 7.544 & $0.006^{\mathrm{a}}$ \\
\hline & & & Kazak & 22 & & Kazak & 10 & & \\
\hline
\end{tabular}

${ }^{\mathrm{a}} \mathrm{P}<0.05$. LN, lymph node metastases; $\mathrm{T} 1$, tumors only invade the lamina propria and submucosa; $\mathrm{T} 2$, tumors invade the muscular layer; $\mathrm{T} 3$, tumors invade the esophageal fibrous membrane; T4, tumors invade adjacent organs; HDAC, histone deacetylase.

cancer (37-39). Huang et al (40), demonstrated that HDAC2 affects chromatin remodeling following DNA damage in ovarian cancer cells. It is also reported that high HDAC2 expression indicates high aggressive behavior in esophageal adenocarcinoma (30). Wang et al (41), noted that the level of HDAC2 increases dramatically in ESCC compared with adjacent non-tumor tissues. Li et al (42) reported that the HDAC2 protein level in ESCC tissues was significantly increased and was closely associated with the histological grade, invasion depth and lymph node metastasis. Göder et al (43) noted that HDAC1 and HDAC2 regulate checkpoint kinase phosphorylation through suppression of PR130. HDACi, as well as an elimination of HDAC1/HDAC2, induces PR130-dependent mechanisms that inhibit checkpoint kinase phosphorylation. However, the present study failed to detect notable changes in HDAC2 expression between ESCC and normal tissues. However, the expression of HDAC2 was related to the invasion depth.

HDAC3 is also an essential factor for cell survival and proliferation in tumors and in maintaining the structure of chromatin and the stability of genome (44). HDAC3 can form large corepressor complexes with N-CoR and SMRT (45). High HDAC3 expression has been found in colon or gastric tumor cells and it has an antiapoptotic function $(46,47)$. High expression of HDAC3 is also noted in gastric cancer, where it is associated with poor prognosis (14). HDAC3 stimulates cell migration of ovarian carcinoma and high HDAC 3 expression indicates poor prognosis of lung adenocarcinoma patients $(48,49)$. Jiao et al $(50)$ found that increased HDAC3 level in the nucleus, but not in the cytoplasm, was related with LN metastasis and advanced clinical staging of pancreatic cancer. It has also been reported that HDAC3 is a risk factor of ESCC and may be used to evaluate the grade of malignancy and prognosis of ESCC (51). The present study found no significant difference in the expression of HDAC 3 in ESCC tissue compared with normal tissue and identified that the expression of HDAC3 was not associated with sex, age, metastasis, degree of esophageal tissue differentiation or the depth of invasion. It was hypothesized that perhaps regional differences and ethnic specificity lead to the discrepancy between the present results and a previous study (51). These results indicate that the expression of HDAC3 has no relationship with the development of ESCC.

Additionally, the present study found that the expression of HDACs in tumor tissue from Kazak people was lower compared with Han people. In ESCC, the positive rate of HDAC1 expression in ESCC tissues was increased compared with normal tissue. The expression of HDAC2 varied according to the invasion depth of ESCC patients. However, HDAC 3 showed no significant expression changes in ESCC and was not correlated with the clinicopathological 
Table IX. Correlation of HDA3 expressions with clinicopathologic characteristics of esophageal squamous cell carcinoma in Han and Kazak patients ( $\mathrm{n}=88)$.

\begin{tabular}{|c|c|c|c|c|c|c|c|c|c|}
\hline \multirow{3}{*}{$\begin{array}{l}\text { Clinicopathological } \\
\text { characteristics }\end{array}$} & \multirow[b]{3}{*}{ Male } & \multicolumn{6}{|c|}{ Expression No. of HDAC3 mRNA } & \multirow{3}{*}{$\begin{array}{c}X^{2} \\
4.666\end{array}$} & \multirow{3}{*}{$\frac{\text { P-value }}{0.031^{\mathrm{a}}}$} \\
\hline & & \multicolumn{3}{|c|}{ Positive (+) No. } & \multicolumn{3}{|c|}{ Negative (-) } & & \\
\hline & & 59 & Han & 37 & 3 & Han & 0 & & \\
\hline & & & Kazak & 22 & & Kazak & 3 & & \\
\hline & Female & 23 & Han & 11 & 3 & Han & 0 & 2.487 & 0.115 \\
\hline & & & Kazak & 12 & & Kazak & 3 & & \\
\hline Age & $<60$ years & 45 & Han & 17 & 1 & Han & 0 & 0.599 & 0.439 \\
\hline & & & Kazak & 28 & & Kazak & 1 & & \\
\hline & $\geq 60$ years & 37 & Han & 28 & 5 & Han & 3 & 0.560 & 0.454 \\
\hline & & & Kazak & 9 & & Kazak & 2 & & \\
\hline LN metastasis & Positive & 43 & Han & 22 & 3 & Han & 1 & 0.357 & 0.550 \\
\hline & & & Kazak & 21 & & Kazak & 2 & & \\
\hline & Negative & 39 & Han & 25 & 3 & Han & 0 & 4.751 & $0.029^{\mathrm{a}}$ \\
\hline & & & Kazak & 14 & & Kazak & 3 & & \\
\hline Differentiation & Well and Moderate & 64 & Han & 35 & 5 & Han & 0 & 5.549 & $0.018^{\mathrm{a}}$ \\
\hline & & & Kazak & 29 & & Kazak & 5 & & \\
\hline & Poor & 18 & Han & 13 & 1 & Han & 0 & 2.287 & 0.130 \\
\hline & & & Kazak & 5 & & Kazak & 1 & & \\
\hline Depth of invasion & $\mathrm{T} 1$ and $\mathrm{T} 2$ & 13 & Han & 5 & 0 & Han & 0 & I & \\
\hline & & & Kazak & 8 & & Kazak & 0 & & \\
\hline & $\mathrm{T} 3$ and $\mathrm{T} 4$ & 69 & Han & 41 & 6 & Han & 2 & 1.536 & 0.215 \\
\hline & & & Kazak & 28 & & Kazak & 4 & & \\
\hline
\end{tabular}

${ }^{\mathrm{a}} \mathrm{P}<0.05$. LN, lymph node metastases; $\mathrm{T} 1$, tumors only invade the lamina propria and submucosa; $\mathrm{T} 2$, tumors invade the muscular layer; $\mathrm{T} 3$, tumors invade the esophageal fibrous membrane; T4, tumors invade adjacent organs; HDAC, histone deacetylase.
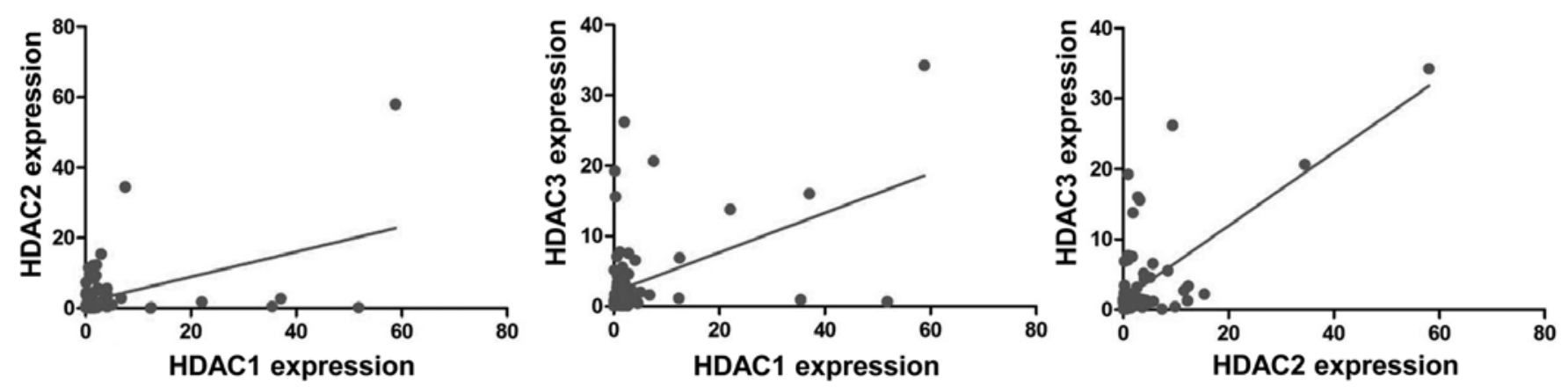

Figure 2. Correlation of $H D A C l,-2$ and -3 expression in human esophageal squamous cell carcinoma $(\mathrm{n}=88)$. Pearson's correlation test was used to analyze the correlation among $H D A C 1,-2$ and -3 . HDAC, histone deacetylase.

characteristics of ESCC patients. The expression of HDACs in tumor tissue of Kazak people was lower compared with Han people. Additionally, it was noted that the expression of HDAC1, -2 and -3 had ethnic differences.

As for treatment, Ahrens et al (52) proposed that targeting epigenetic modifiers in esophageal cancers may represent a potential future therapeutic approach. Kano et al (53) found that CHAP31 sensitized SCC cells to carbon-ion radiotherapy and this combination treatment may be a potentially useful therapeutic strategy for ESCC. Hoshino et al (54) suggested that HDACi-FK228 has a potent ability to augment the effect of adenovirus-mediated p53 gene therapy in ESCC. Thus, targeting HDACs may be an effective approach for treatment of ESCC.

In summary, HDAC1 may be used as a risk factor for ESCC and HDAC2 may be used to predict ESCC invasion. The different clinical parameter expression is related to ethnic differences. Future research should focus on the effect of HDAC inhibitors on ESCC treatment in Xinjiang, China. 


\section{Acknowledgements}

Not applicable.

\section{Funding}

The present study was supported by the Nature Science Foundation of China (grant nos. 81460419 and 81460359).

\section{Availability of data and materials}

All data generated or analyzed during the present study are included in this published article.

\section{Authors' contributions}

LL designed the study. HuiwL, HuiL and YW performed data collection. HuiwL and HuiL performed statistical analysis. HuiwL provided data interpretation. YinL and YikL participated in data collection of patient information. YC and LY provided help in RT-qPCR assay. All authors read and approved the final manuscript.

\section{Ethics approval and consent to participate}

This study was approved by the Ethics Committee of the Xinjiang Medical University and informed consent was obtained from all patients.

\section{Patient consent for publication}

Not applicable.

\section{Competing interests}

All authors declare that they have no competing interests.

\section{References}

1. Wang QL, Xie SH, Wahlin K and Lagergren J: Global time trends in the incidence of esophageal squamous cell carcinoma. Clin Epidemiol 10: 717-728, 2018.

2. Chen W, Zheng R, Baade PD, Zhang S, Zeng H, Bray F, Jemal A, Yu XQ and He J: Cancer statistics in China, 2015. CA Cancer J Clin 66: 115-132, 2016.

3. Parkin DM, Bray FI and Devesa SS: Cancer burden in the year 2000. The global picture. Eur J Cancer 37(Suppl 8): S4-S66, 2001

4. Kohler BA, Ward E, McCarthy BJ, Schymura MJ, Ries LA, Eheman C, Jemal A, Anderson RN, Ajani UA and Edwards BK: Annual report to the nation on the status of cancer, 1975-2007, featuring tumors of the brain and other nervous system. J Natl Cancer Inst 103: 714-736, 2011.

5. Glozak MA and Seto E: Histone deacetylases and cancer. Oncogene 26: 5420-5432, 2007.

6. Hull EE, Montgomery MR and Leyva KJ: HDAC inhibitors as epigenetic regulators of the immune system: Impacts on cancer therapy and inflammatory diseases. Biomed Res Int 2016 : 8797206, 2016.

7. Yamagoe S, Kanno T, Kanno Y, Sasaki S, Siegel RM,Lenardo MJ, Humphrey G, Wang Y, Nakatani Y, Howard BH and Ozato K: Interaction of histone acetylases and deacetylases in vivo. Mol Cell Biol 23: 1025-1033, 2003.

8. Cao LL, Yue Z, Liu L, Pei L, Yin Y, Qin L, Zhao J, Liu H, Wang H and Jia M: The expression of histone deacetylase HDAC1 correlates with the progression and prognosis of gastrointestinal malignancy. Oncotarget 8: 39241-39253, 2017.
9. Nemati M, Ajami N, Estiar MA, Rezapour S, Gavgani RR, Hashemzadeh S, Kafil HS and Sakhinia E: Deregulated expression of HDAC3 in colorectal cancer and its clinical significance. Adv Clin Exp Med 27: 305-311, 2018.

10. Toh Y, Yamamoto M, Endo K, Ikeda Y, Baba H, Kohnoe S, Yonemasu H, Hachitanda Y, Okamura T and Sugimachi K: Histone $\mathrm{H} 4$ acetylation and histone deacetylase 1 expression in esophageal squamous cell carcinoma. Oncol Rep 10: 333-338, 2003.

11. Micheli L, D'Andrea G, Leonardi L and Tirone F: HDAC1, HDAC4, and HDAC9 bind to PC3/Tis21/Btg2 and are required for its inhibition of cell cycle progression and cyclin D1 expression. J Cell Physiol 232: 1696-1707, 2017.

12. Nakashima H, Nguyen T and Chiocca EA: Combining HDAC inhibitors with oncolytic virotherapy for cancer therapy. Oncolytic Virother 4: 183-191, 2015.

13. Yoon S and Eom GH: HDAC and HDAC inhibitor: From cancer to cardiovascular diseases. Chonnam Med J 52: 1-11, 2016.

14. Thangaraju M, Carswell KN, Prasad PD and Ganapathy V: Colon cancer cells maintain low levels of pyruvate to avoid cell mortality caused by inhibition of HDAC1/HDAC3. Biochem J 417: 379-389, 2009.

15. Liu C, Liu L, Shan J, Shen J, Xu Y, Zhang Q, Yang Z, Wu L, Xia F, Bie $\mathrm{P}$, et al: Histone deacetylase 3 participates in self-renewal of liver cancer stem cells through histone modification. Cancer Lett 339: 60-69, 2013.

16. $\mathrm{Xu} \mathrm{G}, \mathrm{Zhu} \mathrm{H}$, Zhang $\mathrm{M}$ and $\mathrm{Xu} \mathrm{J}$. Histone deacetylase 3 is associated with gastric cancer cell growth via the miR-454-mediated targeting of CHD5. Int J Mol Med 41: 155-163, 2018.

17. Taunton J, Hassig CA and Schreiber SL: A mammalian histone deacetylase related to the yeast transcriptional regulator Rpd3p. Science 272: 408-411, 1996.

18. Chen L, Wang C, Luo J, Su W, Li M, Zhao N, Lyu W, Attaran H, $\mathrm{He} \mathrm{Y}$, Ding $\mathrm{H}$ and $\mathrm{He} \mathrm{H}$ : Histone deacetylase 1 plays an acetylation-independent role in influenza a virus replication. Front Immunol 8: 1757, 2017.

19. Datta M,StaszewskiO,RaschiE,Frosch M,Hagemeyer N, Tay TL, Blank T, Kreutzfeldt M, Merkler D, Ziegler-Waldkirch S, et al: Histone deacetylases 1 and 2 regulate microglia function during development, homeostasis, and neurodegeneration in a context-dependent manner. Immunity 48: 514-529, 2018.

20. Qiao W, Liu H, Liu R, Liu Q, Zhang T, Guo W, Li P and Deng M: Prognostic and clinical significance of histone deacetylase 1 expression in breast cancer: A meta-analysis. Clin Chim Acta 483: 209-215, 2018.

21. Sekhavat A, Sun JM and Davie JR: Competitive inhibition of histone deacetylase activity by trichostatin A and butyrate. Biochem Cell Biol 85: 751-758, 2007.

22. Burdelski C, Ruge OM, Melling N, Koop C, Simon R, Steurer S, Sauter G, Kluth M, Hube-Magg C, Minner S, et al: HDAC1 overexpression independently predicts biochemical recurrence and is associated with rapid tumor cell proliferation and genomic instability in prostate cancer. Exp Mol Pathol 98: 419-426, 2015

23. Huang BH, Laban M, Leung CH, Lee L, Lee CK, Salto-Tellez M, Raju GC and Hooi SC: Inhibition of histone deacetylase 2 increases apoptosis and p21Cip1/WAF1 expression, independent of histone deacetylase 1. Cell Death Differ 12: 395-404, 2005.

24. Mutze K, Langer R, Becker K, Ott K, Novotny A, Luber B, Hapfelmeier A, Gottlicher M, Hofler H and Keller G: Histone deacetylase (HDAC) 1 and 2 expression and chemotherapy in gastric cancer. Ann Surg Oncol 17: 3336-3343, 2010.

25. Shinke G, Yamada D, Eguchi H, Iwagami Y, Asaoka T, Noda T, Wada H, Kawamoto K, Gotoh K, Kobayashi S, et al: Role of histone deacetylase 1 in distant metastasis of pancreatic ductal cancer. Cancer Sci 109: 2520-2531, 2018.

26. Zhang Z, Yamashita H, Toyama T, Sugiura H, Ando Y, Mita K, Hamaguchi M, Hara Y, Kobayashi S and Iwase H: Quantitation of HDAC1 mRNA expression in invasive carcinoma of the breast. Breast Cancer Res Treat 94: 11-16, 2005.

27. Wang H, Kohashi K, Yoshizumi T, Okumura Y, Tanaka Y, Shimokawa M, Iwasaki T, Aishima S, Maehara Y and Oda Y: Co-expression of SALL4 with HDAC1 and/or HDAC2 is associated with underexpression of PTEN and poor prognosis in patients with hepatocellular carcinoma. Hum Pathol 64: 69-75, 2017.

28. Zhong L, Zhou S, Tong R, Shi J, Bai L, Zhu Y, Duan X, Liu W, Bao J, Su L and Peng Q: Preclinical assessment of histone deacetylase inhibitor quisinostat as a therapeutic agent against esophageal squamous cell carcinoma. Invest New Drugs 37: 616-624, 2019. 
29. Miyashita T, Tajima H, Munemoto M, Shah FA, Harmon JW, Watanabe T, Shoji M, Okamoto K, Nakanuma S, Sakai S, et al: Impact of histone deacetylase 1 and metastasis-associated gene 1 expression in esophageal carcinogenesis. Oncol Lett 8: 758-764, 2014.

30. Langer R, Mutze K, Becker K, Feith M, Ott K, Hofler H and Keller G: Expression of class I histone deacetylases (HDAC1 and HDAC2) in oesophageal adenocarcinomas: An immunohistochemical study. J Clin Pathol 63: 994-998, 2010.

31. Xu J, Lv H, Zhang B, Xu F, Zhu H, Chen B, Zhu C and Shen J: miR-30b-5p acts as a tumor suppressor microRNA in esophageal squamous cell carcinoma. J Thorac Dis 11: 3015-3029, 2019.

32. Kiweler N, Brill B, Wirth M, Breuksch I, Laguna T, Dietrich C, Strand S, Schneider G, Groner B, Butter F, et al: The histone deacetylases HDAC1 and HDAC2 are required for the growth and survival of renal carcinoma cells. Arch Toxicol 92: 2227-2243, 2018.

33. Fritsche P, Seidler B, Schuler S, Schnieke A, Gottlicher M, Schmid RM, Saur D and Schneider G: HDAC2 mediates therapeutic resistance of pancreatic cancer cells via the BH3-only protein NOXA. Gut 58: 1399-1409, 2009.

34. Witt O, Deubzer HE, Milde T and Oehme I: HDAC family: What are the cancer relevant targets? Cancer Lett 277: 8-21, 2009.

35. Barnes PJ: Histone deacetylase-2 and airway disease. Ther Adv Respir Dis 3: 235-243, 2009.

36. Yao $\mathrm{H}$ and Rahman I: Role of histone deacetylase 2 in epigenetics and cellular senescence: Implications in lung inflammaging and COPD. Am J Physiol Lung Cell Mol Physiol 303: L557-L566, 2012.

37. Brodie SA, Li G, El-Kommos A, Kang H, Ramalingam SS Behera M, Gandhi K, Kowalski J, Sica GL, Khuri FR, et al: Class I HDACs are mediators of smoke carcinogen-induced stabilization of DNMT1 and serve as promising targets for chemoprevention of lung cancer. Cancer Prev Res (Phila) 7: 351-361, 2014.

38. Han Y, Zhang Y, Yang LH, Mi XY, Dai SD, Li QC, Xu HT, $\mathrm{Yu} \mathrm{JH}, \mathrm{Li} \mathrm{G}$, Zhao J, et al: X-radiation inhibits histone deacetylase 1 and 2, upregulates Axin expression and induces apoptosis in non-small cell lung cancer. Radiat Oncol 7: 183, 2012.

39. Jung KH, Noh JH, Kim JK, Eun JW, Bae HJ, Xie HJ, Chang YG, Kim MG, Park H, Lee JY and Nam SW: HDAC2 overexpression confers oncogenic potential to human lung cancer cells by deregulating expression of apoptosis and cell cycle proteins. J Cell Biochem 113: 2167-2177, 2012.

40. Huang R, Langdon SP, Tse M, Mullen P, Um IH, Faratian D and Harrison DJ: The role of HDAC2 in chromatin remodelling and response to chemotherapy in ovarian cancer. Oncotarget 7 : 4695-4711, 2016

41. Wang F, Qi Y, Li X, He W, Fan QX and Zong H: HDAC inhibitor trichostatin A suppresses esophageal squamous cell carcinoma metastasis through HADC2 reduced MMP-2/9. Clin Invest Med 36: E87-E94, 2013.

42. Li S, Wang F, Qu Y, Chen X, Gao M, Yang J, Zhang D, Zhang N, $\mathrm{Li} \mathrm{W}$ and Liu H: HDAC2 regulates cell proliferation, cell cycle progression and cell apoptosis in esophageal squamous cell carcinoma EC9706 cells. Oncol Lett 13: 403-409, 2017.

43. Göder A, Emmerich C, Nikolova T, Kiweler N, Schreiber M, Kühl T, Imhof D, Christmann M, Heinzel T, Schneider G and Krämer $\mathrm{OH}$ : HDAC1 and HDAC2 integrate checkpoint kinase phosphorylation and cell fate through the phosphatase-2A subunit PR130. Nat Commun 9: 764, 2018.
44. Bhaskara S, Knutson SK, Jiang G, Chandrasekharan MB, Wilson AJ, Zheng S, Yenamandra A, Locke K, Yuan JL, Bonine-Summers AR, et al: Hdac3 is essential for the maintenance of chromatin structure and genome stability. Cancer Cell 18: 436-447, 2010.

45. Li J, Jin W, Wang J, Nawaz Z, Liu JM, Qin J and Wong J: Both corepressor proteins SMRT and N-CoR exist in large protein complexes containing HDAC3. EMBO J 19: 4342-4350, 2020.

46. Weichert W, Röske A, Niesporek S, Noske A, Buckendahl AC, Dietel M, Gekeler V, Boehm M, Beckers T and Denkert C: Class I histone deacetylase expression has independent prognostic impact in human colorectal cancer: Specific role of class I histone deacetylases in vitro and in vivo. Clin Cancer Res 14: 1669-1677, 2008.

47. Weichert W, Röske A, Gekeler V, Beckers T, Ebert MP, Pross M, Dietel M, Denkert C and Röcken C: Association of patterns of class I histone deacetylase expression with patient prognosis in gastric cancer: A retrospective analysis. Lancet Oncol 9: 139-148, 2008.

48. Hayashi A, Horiuchi A, Kikuchi N, Hayashi T, Fuseya C, Suzuki A, Konishi I and Shiozawa T: Type-specific roles of histone deacetylase (HDAC) overexpression in ovarian carcinoma: HDAC1 enhances cell proliferation and HDAC3 stimulates cell migration with downregulation of E-cadherin. Int J Cancer 127: 1332-1346, 2010.

49. Minamiya Y, Ono T, Saito H, Takahashi N, Ito M, Motoyama S and Ogawa J: Strong expression of HDAC 3 correlates with a poor prognosis in patients with adenocarcinoma of the lung. Tumour Biol 31: 533-539, 2010.

50. Jiao F, Hu H, Han T, Zhuo M, Yuan C, Yang H, Wang L and Wang L: Aberrant expression of nuclear HDAC3 and cytoplasmic $\mathrm{CDH} 1$ predict a poor prognosis for patients with pancreatic cancer. Oncotarget 7: 16505-16516, 2016.

51. Yao Z, Xu M and Zhou Z: The role of Histone deacetylase 3 in esophageal squamous cell carcinoma pathogenesis. Chin $\mathrm{J}$ Dig 32: 760-762, 2012 (In Chinese).

52. Ahrens TD, Timme S, Hoeppner J, Ostendorp J, Hembach S, Follo M, Hopt UT, Werner M, Busch H, Boerries M and Lassmann S: Selective inhibition of esophageal cancer cells by combination of HDAC inhibitors and Azacytidine. Epigenetics 10: 431-445, 2015.

53. Kano M, Yamada S, Hoshino I, Murakami K, Akutsu Y, Sakata H, Nishimori T, Usui A, Miyazawa Y, Kamada T, et al: Effects of carbon-ion radiotherapy combined with a novel histone deacetylase inhibitor, cyclic hydroxamic-acid-containing peptide 31 in human esophageal squamous cell carcinoma. Anticancer Res 29: 4433-4438, 2009

54. Hoshino I, Matsubara H, Akutsu Y, Nishimori T, Yoneyama Y, Murakami K, Sakata H, Matsushita K, Komatsu A, Brooks R and Ochiai T: Role of histone deacetylase inhibitor in adenovirus-mediated p53 gene therapy in esophageal cancer. Anticancer Res 28: 665-671, 2008.

(i) () $९$ This work is licensed under a Creative Commons

EY No ND Attribution-NonCommercial-NoDerivatives 4.0 International (CC BY-NC-ND 4.0) License. 